\title{
Impact of the Arctic Oscillation pattern on interannual forest fire variability in Central Siberia
}

\author{
Heiko Balzter, ${ }^{1}$ France F. Gerard, ${ }^{1}$ Charles T. George, ${ }^{1}$ Clare S. Rowland, ${ }^{1}$ Tim E. Jupp, ${ }^{1}$ \\ Ian McCallum, ${ }^{2}$ Anatoly Shvidenko, ${ }^{2}$ Sten Nilsson, ${ }^{2}$ Anatoly Sukhinin, ${ }^{3}$ \\ Alexander Onuchin, ${ }^{3}$ and Christiane Schmullius ${ }^{4}$ \\ Received 27 January 2005; revised 23 May 2005; accepted 15 June 2005; published 26 July 2005.
}

[1] Russia's forests play an important role in the global carbon cycle. Because of their scale and interannual variability, forest fires can change the direction of the net carbon flux over Eurasia. 2002 and 2003 were the first two consecutive years in the atmospheric record in which the carbon content rose by more than $2 \mathrm{ppm}$ per year. Northern Hemisphere fires could be the reason. We show that 2002 and 2003 were the two years with the largest fire extent in Central Siberia since 1996 using new measurements of burned forest area in Central Siberia derived from remote sensing. To quantify the relationship between Siberian forest fires and climate variability, we compare these measurements with time-series of large-scale climatic indices for the period 1992-2003. This paper is amongst the first studies that analyse statistical relationships between interannual variability of forest fires in Russia and climate indices. Significant relationships of annual burned forest area with the Arctic Oscillation, summer temperatures, precipitation, and the El Niño index NINO4 were found $(\mathrm{p}<0.1)$. In contrast, we find no significant relation with the El Niño indices NINO1, NINO3 or SOI $(\mathrm{p}>0.1)$. Interannual forest fire variability in Central Siberia could best be explained by a combination of the Arctic Oscillation index and regional summer temperatures $\left(r^{2}=0.80\right)$. Citation: Balzter, H., et al. (2005), Impact of the Arctic Oscillation pattern on interannual forest fire variability in Central Siberia, Geophys. Res. Lett., 32, L14709, doi:10.1029/ 2005GL022526.

\section{Introduction}

[2] Yurganov et al. [2004] and Jones and Cox [2005] have observed a higher than expected increase in atmospheric carbon concentrations in 2002 and 2003. This is the first time that in two consecutive years carbon dioxide concentrations in the Mauna Loa record have risen by more than 2 ppm/a [Jones and Cox, 2005]. Northern Hemisphere fires have been suggested as a likely cause for this phenomenon [Jones and Cox, 2005]. The current $\mathrm{CO}_{2}$ concentration in the atmosphere is approximately $370 \mathrm{ppm}$, which

\footnotetext{
${ }^{1}$ Climate and Land Surface Systems Interaction Centre, Centre for Ecology and Hydrology (CEH) Monks Wood, Cambridgeshire, UK.

${ }^{2}$ International Institute for Applied Systems Analysis (IIASA), Laxenburg, Austria.

${ }^{3}$ V. N. Sukachev Institute of Forest, Siberian Branch Russian Academy of Sciences, Academgorodok, Krasnoyarsk, Russia.

${ }^{4}$ Institut für Geographie der Universität Jena, Jena, Germany.
}

Copyright 2005 by the American Geophysical Union. 0094-8276/05/2005GL022526\$05.00 equates to a total atmospheric carbon pool of $730 \mathrm{Pg} \mathrm{C}$ [Intergovernmental Panel on Climate Change, 2001].

[3] Greenhouse gas emissions from fires are an important component in the global carbon cycle and fire is the most important ecological disturbance worldwide releasing approximately $3.5 \mathrm{Pg} \mathrm{C}$ per annum into the atmosphere [van der Werf et al., 2004]. If this were the only carbon flux between land and atmosphere it would produce a rise in $\mathrm{CO}_{2}$ concentration of $1.77 \mathrm{ppm} / \mathrm{a}$. Increased greenhouse gas emissions may lead to a positive feedback between forest fires and climate change, so enhancing global warming [Amiro et al., 2001].

[4] Interannual variability in the carbon balance of forests has been associated with climatic variations such as the El Niño Southern Oscillation in tropical and extra-tropical regions [Schimel et al., 2001]. In the El Niño years of 1997-98 fire emissions of greenhouse gases increased across multiple continental regions, $60 \%$ of which was attributed to Southeast Asia, 30\% to Central and South America, and $10 \%$ to the boreal forests of North America and Eurasia [van der Werf et al., 2004].

[5] Regional fire regimes in the boreal biome may be linked to climate via large-scale atmospheric circulation patterns, as suggested by an analysis of the long-term fire regime of British Columbia during the Holocene [Hallett et al., 2003]. The anticipated future climate change in the Northern Hemisphere, with an increasingly dry and hot summer climate, may lead to increased insect damage to vegetation and increased susceptibility of the boreal biome to fire [Kobak et al., 1996; Ayres and Lombardero, 2000].

[6] Here, we quantify the relationship between several large-scale climate indices and the interannual variability of burned forest over 3 million $\mathrm{km}^{2}$ of Central Siberia, a region comprised of the administrative regions of Irkutsk Oblast, Krasnoyarsk Kray, Taimyr, Khakass Republic, Buryat Republic and Evenksky Autonomous Oblast (approx. 79$\left.119^{\circ} \mathrm{E}, 51-78^{\circ} \mathrm{N}\right)$.

\section{Methodology}

[7] Satellite-based vegetation indices were used to estimate the burned forest area of Central Siberia, and to attribute areas to the year of the fire. Spectrally distinct disturbed forest areas were mapped using optical and thermal remote sensing data. Those areas which showed a thermal anomaly (heat emission) at any time between 1992 and 2003 were classified as a forest fire. The spectral signatures of a healthy forest are different from those of a partially destroyed forest. Healthy green vegetation absorbs electromagnetic radiation in the red wavelengths (RED: 
a

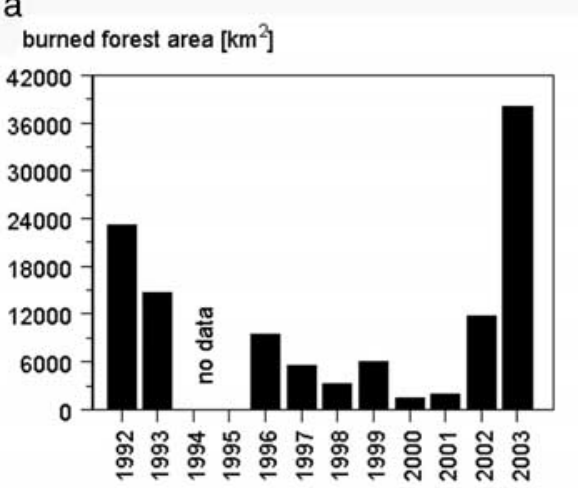

C

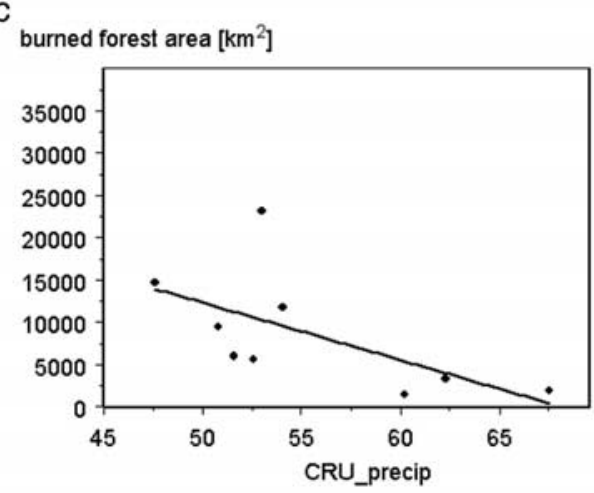

b

burned forest area $\left[\mathrm{km}^{2}\right]$

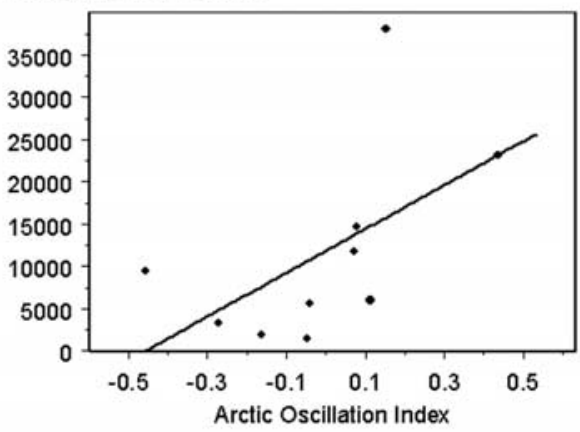

$\mathrm{d}$

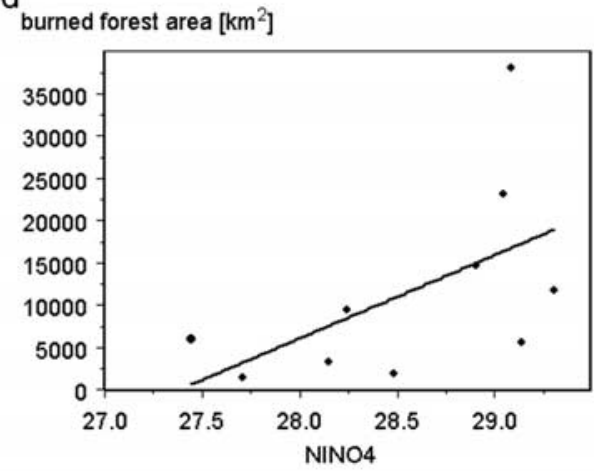

Figure 1. (a) Annual burned forest area statistics for Central Siberia from 1992-2003 derived from remote sensing (SIBERIA-2 dataset); (b) linear regression model of annual burned forest area $\left(b_{o b s}\right)$ in Central Siberia (SIBERIA-2 data) as a function of the Arctic Oscillation Index (Table 1); (c) regression model of $b_{o b s}$ as a function of the CRU summer precipitation (Table 1); (d) regression model of $b_{o b s}$ as a function of NINO4 Index (Table 1). The CRU temperature plot is not shown but is significant at the $10 \%$ level as well.

$0.6 \mu \mathrm{m}-0.7 \mu \mathrm{m})$ through chlorophyll absorption, scatters light in the near-infrared (NIR: $0.7 \mu \mathrm{m}-1.3 \mu \mathrm{m}$ ) through intra-cellular scattering and absorbs in the shortwaveinfrared (SWIR: $1.4 \mu \mathrm{m}-1.8 \mu \mathrm{m}$ ) through plant moisture absorption. After a forest fire more soil is exposed and some or all of the forest will have been destroyed. This generally results in a spectral signature showing higher RED, lower NIR and higher SWIR reflectance, although charcoal on the surface can temporarily lower the red signal. The radiance or reflectance in the different spectral bands (RED, NIR, and SWIR) can be combined to produce vegetation indices [Hall et al., 1995]. One such index is the Normalized Difference Short-Wave Infrared Index NDSWIR which is sensitive to canopy moisture content and canopy structure, and allows gaps in the canopy to be detected for a long time after the canopy gap has started to be colonized by plant species in post-disturbance successional stages [Fraser and $L i, 2002]$. This index together with other data was used to derive a time-series of burned forest areas of Central Siberia between 1992 and 2003, the longest available time series of burned forest area data (referred to here as the SIBERIA-2 dataset; see Figure 1).

[8] Fire scars from 1992 to 2003 were mapped based on the Normalized Difference Short-Wave Infrared Index NDSWIR $=($ NIR - SWIR $) /($ NIR + SWIR $)$ based on MODIS/Terra $1 \mathrm{~km}$ MOD43B4 data. Gerard et al. [2003] showed that this index is able to map fire scars in boreal forest of up to about 15 years of age. The date of the disturbance was determined from thermal anomaly point data, which indicate detections of active fires (or other 'hotspots') made by AVHRR (07/1992-12/1993), ATSR-2 (1995-2000) and MODIS MOD14A2 (2001-2003). Processing involved (i) creation of a mask of combustible woody vegetation based on the IGBP Global Land Cover Characteristics Data Base 1992 (classes 1-8); (ii) derivation of NDSWIR index from a mosaic of eight 16-day composite MODIS NBAR images from Julian day 113 to 225; (iii) masking out low quality pixels in the MODIS images (according to N-BAR procedure or NDSWIR > 1.4); (iv) image segmentation using the CAESAR algorithm [Cook et al., 1994] with parameters $\mathrm{P}=0.01$ and $\mathrm{L}=50$; (v) division of segmentation into two land categories (IGBP classes $1-5$ forest; 6-8 shrub lands); (vi) computation of contrast between segments and their brighter adjacent neighboring segments $\delta_{i}=\sum_{j}\left(l_{i, j} \cdot\left(\mathrm{NDSWIR}_{j}-\right.\right.$ $\mathrm{NDSWIR}_{i}$ )) $\forall \mathrm{NDSWIR}_{j}>\mathrm{NDSWIR}_{i}$ (where $\delta_{i}=$ contrast of segment $i ; l_{i, j}=$ boundary length of neighboring segments $i$ and $j ; N D S W I R_{i}=$ mean NDSWIR of segment $i$ ) using a contextual algorithm, separately applied to each land category; (vii) identification of segments as disturbances if $\delta_{i}$ exceeded a threshold depending on land category ( 6.45 for forest; 9.5 for shrub land). The thresholds were determined from visual comparisons with the original image, presence of thermal anomalies, and higher resolution imagery (Landsat ETM+); (viii) dating the fire scars using thermal anomalies 
Table 1. Linear Regression Models of Annual Burned Forest Area $\left(\mathrm{km}^{2}\right)$ in Central Siberia ${ }^{\mathrm{a}}$

\begin{tabular}{|c|c|c|c|c|}
\hline Stage & Index & $r^{2}$ & $\mathrm{p}$ & Model \\
\hline \multirow[t]{7}{*}{1} & $\mathrm{p}_{\mathrm{CRU}}[\mathrm{mm}]$ & 0.38 & 0.077 & \multirow{7}{*}{$\begin{aligned} \mathrm{ba} & =46313 \\
& -679 * \mathrm{p}_{\mathrm{CRU}} \\
\mathrm{ba} & =67172 \\
& -5687 * \mathrm{t}_{\mathrm{CRU}} \\
\mathrm{ba} & =11845 \\
& +25941 * \mathrm{AO} \\
\mathrm{ba} & =-269965 \\
& +9860 * \text { NINO4 }\end{aligned}$} \\
\hline & $\mathrm{t}_{\mathrm{CRU}}\left[{ }^{\circ} \mathrm{C}\right]$ & 0.36 & 0.087 & \\
\hline & $\mathrm{AO}$ & 0.31 & 0.093 & \\
\hline & NINO4 & 0.31 & 0.095 & \\
\hline & NINO1 & n.s. & 0.673 & \\
\hline & NINO3 & n.s. & 0.282 & \\
\hline & SOI & & 0.269 & \\
\hline \multirow[t]{5}{*}{2} & $\mathrm{AO}+\mathrm{t}_{\mathrm{CRU}}$ & 0.80 & 0.008 & \multirow{5}{*}{$\begin{array}{l}\mathrm{ba}=68747+18356 \\
* \mathrm{AO}-5785 * \mathrm{t}_{\mathrm{CRU}} \\
\mathrm{ba}=-112958+6382 \\
* \mathrm{NINO}-5851 * \mathrm{t}_{\mathrm{CRU}} \\
\mathrm{ba}=37199+12168 \\
* \mathrm{AO}-508 * \mathrm{p}_{\mathrm{CRU}} \\
\mathrm{ba}=-97553+4807 \\
\quad * \mathrm{NINO} 4-555 * \mathrm{p}_{\mathrm{CRU}}\end{array}$} \\
\hline & $\mathrm{NINO} 4+\mathrm{t}_{\mathrm{CRU}}$ & 0.71 & 0.024 & \\
\hline & $\mathrm{AO}+\mathrm{p}_{\mathrm{CRU}}$ & 0.62 & 0.057 & \\
\hline & $\mathrm{NINO} 4+\mathrm{p}_{\mathrm{CRU}}$ & 0.57 & 0.082 & \\
\hline & $\begin{array}{l}\text { tCRU + pCRU } \\
\mathrm{AO}+\mathrm{NINO4}\end{array}$ & $\begin{array}{l}\text { n.s. } \\
\text { n.s. }\end{array}$ & $\begin{array}{l}0.125 \\
0.121\end{array}$ & \\
\hline
\end{tabular}

${ }^{\mathrm{a}} \mathrm{ba}=$ burned area [SIBERIA-2]; $\mathrm{AO}=$ Arctic Oscillation index, NINO1,3,4 $=$ El Niño SST indices, SOI $=$ Southern Oscillation Index, $t_{C R U}=$ mean summer temperature (April-September) from CRU; $p_{C R U}=$ mean summer precipitation from CRU. n.s. $=$ not significant at the $10 \%$ level. Stage $1=$ single regressions, stage $2=$ dual regressions based on stage 1 results.

excluding polygons not associated to a hotspot as "undated"; (ix) removal of river valleys by buffering of 2 pixels around rivers; (x) removal of permanent wetlands using a land cover map by the University of Swansea. (This map [Le Toan et al., 2004] was classified with a decision tree classifier, c5.0, trained with $\sim 1000$ forest inventory polygons that represent the level 2 MODIS land cover classes.) Because some image acquisition dates for the NDSWIR method were early in the 2003 fire season, fires later in 2003 were not completely detected, so NDVI-derived fire scar areas for 2003 were added to the burned area map. A normalized difference vegetation index (NDVI) differencing method was applied to MODIS43B4 2002 and 2003 imagery. The NDVI is defined as NDVI $=(\mathrm{NIR}-\mathrm{RED}) /(\mathrm{NIR}+\mathrm{RED})$ where RED and NIR are the reflectance in the red and near-infrared bands respectively. Four pairs of images for corresponding time periods (28 July-28 September) in 2002 and 2003 were used. An NDVI decrease was only identified as a potential burnt area if the NDVI decrease exceeded 10\% change in NDVI on 2 -dates or a change of $5 \%$ for 3 -dates. The NDVI thresholds were determined visually using the hotspots, MODIS images and Landsat data. An accuracy assessment of the burned area map was carried by comparing it to 19 manually digitized Landsat ETM images (7 from 2002; 9 from 2001) selected to represent the range of land cover types within the region. Thermal anomalies were overlaid on the Landsat images in some cases to aid the classification of the fire scars, but uncertain areas were left unclassified. The thematic accuracy of the fire scar map was estimated at $80 \%$ correctly classified pixels $(\kappa=0.612)$. Due to a lack of multitemporal Landsat data we could not validate the temporal attribution of fire scars to years.

[9] The thermal anomaly products (from AVHRR, ATSR-2 and MODIS confidence levels 1-3) used for determination of the date of the fire have different errors of false alarms and omissions of heat sources [Kasischke et al., 2003]. An algorithm was developed that attributes proportions of the burned forest area within each segment to different years based on a weighting factor. The annual false alarm rate of the thermal anomaly data was defined as the mean number of hotspots in areas of combustible woody vegetation outside the NDSWIR derived disturbance polygons and was smallest in $2000\left(0.000016 \mathrm{~km}^{-2}\right)$ and greatest in $2003\left(0.005545 \mathrm{~km}^{-2}\right)$. The weight is proportional to the number of hotspots in the segment and inversely proportional to the false alarm rate of the hotspot data in that year. The annual burned area $a_{p, t}$ of segment $p$ in year $t$ was calculated as $a_{p, t}=\left(s_{p} \cdot h_{p, t} \cdot w_{t}^{\prime}\right) / Z_{p}$ (where; $s_{p}=$ area of fire scar within the segment $\left[\mathrm{km}^{2}\right] ; h_{p, t}=$ mean number of hotspots per segment area in segment $p$ and year $t ; w_{t}^{\prime}=$ weighting factor for year $t ; w_{t}^{\prime}=\left(w_{t} / \Sigma w_{t}\right) ; w_{t}=1 / u_{t} ; Z_{p}=$ $\sum\left(h_{p, t} * w_{t}{ }^{\prime}\right) ; u_{t}=$ mean number of hotspots per total unburnt area for year $t$ over all unburnt segments; $Z_{p}=$ normalization constant for segment $p$ ).

\section{Results and Discussion}

[10] We compared the SIBERIA-2 burned area timeseries with a variety of climatic variables in a two-stage analysis. ${ }^{1}$ In stage 1 single regressions of annual burned area against climate variables were carried out. AO, NINO4, $\mathrm{t}_{\mathrm{CRU}}$ and $\mathrm{p}_{\mathrm{CRU}}$ were statistically significant at the $10 \%$ level. (Table 1) Out of the climate indices that characterize the El Niño/Southern Oscillation pattern only NINO4 resulted in a statistically significant linear model $(\mathrm{p}<0.1)$, which suggests that the relationship between El Niño and forest fires in Siberia is inconclusive. $\mathrm{r}^{2}$ values range from 0.31 to 0.38 for single regression (Table 1).

[11] In stage 2 for the four indices that were significant $(\mathrm{p}<0.1)$, pairwise dual regressions were carried out. The best model fit was found for the $\mathrm{AO}+\mathrm{t}_{\mathrm{CRU}}$ model $\left(\mathrm{r}^{2}=\right.$ $0.80 ; \mathrm{p}<0.1$; Table 1$)$. In the single regression, mean annual summer temperature of Central Siberia during the fire season (April to September) had a negative relationship to burned area (Table 1) (see auxiliary material). This may be because under conditions of low pressure weather systems higher temperatures tend to be correlated with dense cloud cover trapping heat and at the same time with increased precipitation. Under high pressure systems, on the other hand, higher temperatures are thought to cause drying of the phytomass. The Arctic Oscillation index can serve as an indicator for the prevailing large-scale weather system. In the dual model including the $\mathrm{AO}$, greater temperatures correspond to greater burned areas (see model equation in Table 1). Other significant dual regression models were found for combinations of $\mathrm{NINO} 4 /$ temperature, $\mathrm{AO} /$ precipitation, and NINO4/precipitation $(\mathrm{p}<0.1$, Table 1).

[12] The AO index quantifies the difference in atmospheric pressure between the northern middle and high latitudes. When the AO is in its positive phase, the model shows an increase in annual burned area. A positive value of AO indicates higher pressure at mid-latitudes, which brings higher than normal temperatures to northern Eurasia

${ }^{1}$ Auxiliary material is available at $\mathrm{ftp}: / / \mathrm{ftp}$.agu.org/apend/gl/ 2005 GL022526. 
[Thompson and Wallace, 1998]. This leads to enhanced greening conditions over large regions in Europe and Asian Russia that have been detected by satellite-derived vegetation indices [Buermann et al., 2003]. This suggests a possible causal link between the Arctic Oscillation and Siberian forest fires: Large-scale climatic conditions conducive to increased biomass availability and reduced water availability may also lead to positive values of AO.

[13] Fire regimes are influenced by a complex combination of climate, vegetation type, soil and litter composition, human actions and land use. Climatic variability will have an impact on soil and vegetation moisture content and the flammability of the combustible material. It is plausible that higher regional temperatures lead to an increased risk of ignition of the available biomass.

[14] A tree ring based reconstruction of the AO from 1650 to the present suggests a stronger positive phase of the AO in the twentieth century [D'Arrigo et al., 2003]. Whether this phenomenon is associated with climate change or a reversible fluctuation is unclear. If it were to persist, a consequence would be an increased risk of fire damage in Siberia, which has profound impacts on the ability of the forest to regenerate after fire.

[15] In summary, the burned area of forest fires in Central Siberia for the period 1992-2002 can largely be reproduced by a linear combination of two factors - the large-scale climate represented by the Arctic Oscillation index and the summer temperature. This suggests that interannual climate variability in the Northern Hemisphere could play a major role in determining carbon emissions from forest fires in Siberia. The results for the examined El Niño indices are inconclusive. A simple calculation illustrates the impact of forest fires within Central Siberia. Assuming that the 2003 burned area of $38,000 \mathrm{~km}^{2}$ (Figure 1) released $20 \mathrm{t} \mathrm{C}^{-1}$ into the atmosphere [Kasischke and Penner, 2004] gives a total of $0.08 \mathrm{Pg} \mathrm{C}$. This is about $2 \%$ of the global flux from fires of 3.5 Pg C per annum [van der Werf et al., 2004]. The high amounts of burned area in 2002 and 2003 detected from remote sensing may help explain the observed atmospheric carbon growth-rate anomalies [Jones and Cox, 2005] in those years. The strongly negative carbon growth-rate anomalies in 1992 and 1993, which were also experiencing intense forest fires, are probably due to the effects of the Pinatubo eruption in 1991. This cooled the planet, suppressed soil respiration, and enhanced the land carbon sink [Jones and Cox, 2001].

[16] Acknowledgments. The SIBERIA-2 project, Multi-Sensor concepts for Greenhouse Gas Accounting in Northern Eurasia, was supported by the 5th Framework Programme of the European Commission, contract No.: EVG1-CT-2001-00048. Project coordination: Chris Schmullius, FriedrichSchiller University Jena.

\section{References}

Amiro, B. D., B. J. Stocks, M. E. Alexander, M. D. Flannigan, and B. M. Wotton (2001), Fire, climate change, carbon and fuel management in the Canadian boreal forest, Int. J. Wildland Fire, 10, 405-413.

Ayres, M. P., and M. J. Lombardero (2000), Assessing the consequences of global change for forest disturbance from herbivores and pathogens, $\mathrm{Sci}$. Total Environ., 262, 263-286.
Buermann, W., B. Anderson, C. J. Tucker, R. E. Dickinson, W. Lucht, C. S. Potter, and R. B. Myneni (2003), Interannual covariability in Northern Hemisphere air temperatures and greenness associated with El NiñoSouthern Oscillation and the Arctic Oscillation, J. Geophys. Res., 108(D13), 4396, doi:10.1029/2002JD002630.

Cook, R., I. McConnell, and C. Oliver (1994), MUM (Merge Using Moments) segmentation for SAR images, Proc. SPIE Int. Soc. Opt. Eng., 2316, 92-103.

D’Arrigo, R. D., E. R. Cook, M. E. Mann, and G. C. Jacoby (2003), Treering reconstructions of temperature and sea-level pressure variability associated with the warm-season Arctic Oscillation since AD 1650 , Geophys. Res. Lett., 30(11), 1549, doi:10.1029/2003GL017250.

Fraser, R. H., and Z. Li (2002), Estimating fire-related parameters in boreal forest using SPOT VEGETATION, Remote Sens. Environ., 82, 95-110.

Gerard, F., S. Plummer, R. Wadsworth, A. F. Sanfeliu, L. Iliffe, H. Balzter, and B. Wyatt (2003), Forest fire scar detection in the boreal forest with multitemporal SPOT-VEGETATION data, IEEE Trans. Geosci. Remote Sens., 41, 2575-2585.

Hall, F. G., J. R. Townshend, and E. T. Engman (1995), Status of remotesensing algorithms for estimation of land-surface state parameters, Remote Sens. Environ., 51, 138-156.

Hallett, D. J., D. S. Lepofsky, R. W. Mathewes, and K. P. Lertzman (2003), 11000 years of fire history and climate in the mountain hemlock rain forests of southwestern British Columbia based on sedimentary charcoal, Can. J. For. Res., 33, 292-312.

Intergovernmental Panel on Climate Change (2001), Climate Change 2001: The Scientific Basis: Contribution of Working Group I to the Third Assessment Report of the Intergovernmental Panel on Climate Change, edited by J. T. Houghton et al., 881 pp., Cambridge Univ. Press, New York.

Jones, C. D., and P. M. Cox (2001), Modeling the volcanic signal in the atmospheric $\mathrm{CO}_{2}$ record, Global Biogeochem. Cycles, 15, 453-465.

Jones, C., and P. Cox (2005), Atmospheric $\mathrm{CO}_{2}$ growth rate anomalies in 2002 and 2003, Geophys. Res. Lett., 32, L14816, doi:10.1029/ 2005 GL023027.

Kasischke, E. S., and J. E. Penner (2004), Improving global estimates of atmospheric emissions from biomass burning, J. Geophys. Res., 109, D14S01, doi:10.1029/2004JD004972.

Kasischke, E. S., J. H. Hewson, B. Stocks, G. van der Werf, and J. Randerson (2003), The use of ATSR active fire counts for estimating relative patterns of biomass burning-A study from the boreal forest region, Geophys. Res. Lett., 30(18), 1969, doi:10.1029/2003GL017859.

Kobak, K. I., I. Y. Turchinovich, N. Y. Kondrasheva, E. D. Schulze, W. Schulze, H. Koch, and N. N. Vygodskaya (1996), Vulnerability and adaptation of the larch forest in eastern Siberia to climate change, Water Air Soil Pollut., 92, 119-127.

Le Toan, T., et al. (2004), Deliverable 51 "Earth Observation Products", SIBERIA-2 project, report, Eur. Comm., Brussels.

Schimel, D. S., et al. (2001), Recent patterns and mechanisms of carbon exchange by terrestrial ecosystems, Nature, 414, 169-172.

Thompson, D. W. J., and J. M. Wallace (1998), The Arctic Oscillation signature in the wintertime geopotential height and temperature fields, Geophys. Res. Lett., 25, 1297-1300.

van der Werf, G. R., J. T. Randerson, G. J. Collatz, L. Giglio, P. S. Kasibhatla, A. F. Arellano, S. C. Olsen, and E. S. Kasischke (2004), Continental-scale partitioning of fire emissions during the 1997 to $2001 \mathrm{El} \mathrm{Nino/La} \mathrm{Nina}$ period, Science, 303, 73-76.

Yurganov, L., et al. (2004), Increased Northern Hemispheric carbon monoxide burden in the troposphere in 2002 and 2003 detected from the ground and from space, Atmos. Chem. Phys. Discuss., 4, 4999-5017.

H. Balzter, C. T. George, F. F. Gerard, T. E. Jupp, and C. S. Rowland, Climate and Land Surface Systems Interaction Centre, Centre for Ecology and Hydrology (CEH) Monks Wood, Abbots Ripton, Huntingdon, Cambridgeshire PE28 2LS, UK. (hbal@ceh.ac.uk)

I. McCallum, S. Nilsson, and A. Shvidenko, International Institute for Applied Systems Analysis (IIASA), Schlossplatz 1, A-2361 Laxenburg, Austria. (nilsson@iiasa.ac.at)

A. Onuchin and A. Sukhinin, V. N. Sukachev Institute of Forest, Siberian Branch Russian Academy of Sciences, Academgorodok, 660036 Krasnoyarsk, Russia. (onuchin@ksc.krasn.ru)

C. Schmullius, Institut für Geographie der Universität Jena, Löbdergraben 32, D-07743 Jena, Germany. (c.schmullius@uni-jena.de) 